\title{
Seasonal variation in dry weight and elemental composition of the early developmental stages of Petrolisthes laevigatus (Guérin, 1835) (Decapoda: Porcellanidae) in the Seno de Reloncaví, southern Chile
}

\author{
P. Gebauer $\cdot$ K. Paschke $\cdot$ A. Barría $\cdot$ \\ K. Anger
}

Received: 9 January 2012/Revised: 21 May 2012/ Accepted: 5 June 2012/Published online: 21 June 2012

(C) Springer-Verlag and AWI 2012

\begin{abstract}
In the Seno de Reloncaví, southern Chile, seasonal changes in dry weight (DW) and elemental composition (CHN) were studied in embryo (initial embryonic stage), newly hatched zoeae, and newly settled megalopae of a porcelain crab, Petrolisthes laevigatus. Samples were taken throughout the seasons of egg laying (March-December), hatching (August-February), and settlement (October-February). Values of DW and CHN per embryo or larva, respectively, were consistently minimum in the middle of each season and maximum near its beginning and end. Patterns of seasonal variation in early embryonic biomass may thus be carried over to larvae at hatching and, possibly, to the settlement stage. Such carryover effects may be selectively advantageous, as zoeae released at the beginning or near the end of the hatching season face conditions of poor planktonic food availability in combination with low winter temperatures or decreasing temperatures at the end of summer (enforcing long development duration). Hence, an enhanced female energy allocation into egg production may subsequently translate to enhanced yolk reserves remaining at hatching, allowing for a larval development under unfavourable winter
\end{abstract}

Communicated by Heinz-Dieter Franke.

P. Gebauer $(\bowtie) \cdot$ A. Barría

Centro I-MAR, Universidad de Los Lagos,

Casilla 557, Puerto Montt, Chile

e-mail:pgebauer@ulagos.cl

K. Paschke

Instituto de Acuicultura, Universidad Austral de Chile, Casilla 1327, Puerto Montt, Chile

K. Anger

Biologische Anstalt Helgoland, Stiftung Alfred-Wegener-Institut für Polar- und Meeresforschung, 27498 Helgoland, Germany conditions. In summer, by contrast, plankton productivity and temperatures are generally high, allowing for fast larval growth and development. This coincides with minimal biomass and energy contents both at hatching and settlement. In conclusion, our data suggest that seasonal patterns in the biomass of early developmental stages of $P$. laevigatus may reflect phenotypic variability as an adaptive response to predictable variations in environmental conditions, allowing this species to reproduce in temperate regions with marked seasonality in water temperature and plankton productivity.

Keywords Bioenergetic traits variability - Embryo . Larvae - Elemental composition - Petrolisthes laevigatus . Seasonal variability

\section{Introduction}

Population demographics and dynamics of marine invertebrates are consequences of pre- and post-settlement processes (Connell 1985; Gaines and Rougharden 1985; Grosberg and Levitan 1992; Giménez 2004). Analysis of life-history traits is thus critical for an understanding of these aspects of population biology. Life-history patterns have generally been considered as adaptive, because they are subject to environmental pressures of evolutionary selection towards an optimization of the survival of progeny (Roff 1992; Stearns 1992; Levin and Bridges 1995). However, both physical and biological conditions can modify some traits, indicating phenotype plasticity (Pfennig et al. 2010). Intraspecific variations in various life-history traits have been found, for instance, in crustaceans and other marine invertebrates (Hines 1986a, b; Anger 2001, 2006). Among these intraspecifically variable traits, offspring size 
has been considered as particularly important, because it affects developmental time, survival in the plankton, and the success of recruitment (Miner et al. 2005; Marshall and Keough 2006; Moran and McAlister 2009). Such variations in offspring size have been studied mainly across the latitudinal range of distribution of species, whose populations may live under different environmental conditions (Brante et al. 2004; Ouellet and Plante 2004; Rotllant et al. 2004; Bas et al. 2007; Lardies et al. 2010; Weiss et al. 2010).

Seasonal variations in environmental factors such as temperature and food supply have been identified, in general, as important causes of intrapopulational variability in reproductive traits of marine invertebrates (Ghiselin 1987). However, such variations have not extensively been studied in decapod crustaceans. Seasonal differences have been found, for instance, in the number and volume of anomuran and brachyuran crab eggs (Sampedro et al. 1997; Bas et al. 2007), in the elemental composition of shrimp and crab embryos (Paschke 1998; Bas et al. 2007; Urzúa et al. 2012) and in the biochemical composition of blue crab embryos (O'Leary Amsler and George 1984). Furthermore, seasonal variations have been identified in the nutritional vulnerability of first-stage larval shrimp (Crangon crangon; Paschke et al. 2004) and porcelain crab (Petrolisthes laevigatus; Gebauer et al. 2010).

The species P. laevigatus (Guérin 1835) is a filterfeeding crab that typically inhabits mid-upper rocky intertidal zones on the Pacific coast of South America. Its geographic range extends from the south of Peru $\left(12^{\circ} \mathrm{S}\right)$ to southern Chile $\left(46^{\circ} \mathrm{S}\right)$ (Retamal 1981). Near the southern limit of this range, in the Seno de Reloncaví $\left(41^{\circ} 45^{\prime} \mathrm{S}\right.$, $72^{\circ} 20^{\prime} \mathrm{W}$ ), females with early eggs are present from March to January-February, whereas final embryonic stages are mainly found between August and February (Gebauer et al. 2007). The embryonic development may last up to approximately five months (Gebauer et al. 2007). Female $P$. laevigatus are able to reproduce at least twice during each reproductive season (Gebauer, personal observation).

In southern-Central Chile, the eggs of $P$. laevigatus in an initial embryonic stage have a volume of about $0.23 \mathrm{~mm}^{3}$ and a dry weight of ca $88 \mu \mathrm{g}$ (Lardies and Wehrtmann 1996). The release of the larvae extends for 7 months, from August to February (Gebauer et al. 2007), with different cohorts showing differential nutritional vulnerability (Gebauer et al. 2010). The nutritional vulnerability index (NVI; Gebauer et al. 2010) fluctuates between 2.2 and 1.7 in August and October, respectively, indicating high values of point of reserve saturation and low values of point of no return, representing high dependence on food of early larval stage (Gebauer et al. 2010). The settlement period of this species extends over six months, from October to March, showing both inter- and intra-annual variations in settler abundance (Gebauer et al. 2007, 2011). Due to the long duration of the periods of egg laying, larval hatching, and megalopal settlement, females and early developmental stages (embryos, zoeae, megalopae) face seasonally variable environmental conditions.

In a temperate environment, as Seno de Reloncaví, with marked seasonality in temperature, ranging between $4{ }^{\circ} \mathrm{C}$ (August) and $17^{\circ} \mathrm{C}$, (January) in the intertidal zone (Gebauer et al. 2007) or between $9{ }^{\circ} \mathrm{C}$ (July) and $17{ }^{\circ} \mathrm{C}$ (February) in the water column, while primary productivity fluctuates approximately between $1 \mathrm{mg} \mathrm{C} \mathrm{m}^{-3} \mathrm{~h}^{-1}$ (winter) and $23-12 \mathrm{mg} \mathrm{C} \mathrm{m}^{-3} \mathrm{~h}^{-1}$ (spring and fall) (Iriarte et al. 2007), the occurrence of embryos, early larvae, and settlers of $P$. laevigatus throughout extended periods raises the question whether these early developmental stages differ intra-annually in biomass, elemental composition, and/or quality (expressed in terms of energy content). If these aspects show variability, this might indicate an adaptive strategy to face the seasonally or latitudinally variable conditions.

\section{Materials and methods}

Throughout the periods of egg laying, hatching, and settlement, porcelain crabs ( $P$. laevigatus) were regularly collected from the intertidal zone of Pelluhuín, Seno de Reloncaví, Chile $\left(41^{\circ} 45^{\prime} \mathrm{S}, 72^{\circ} 20^{\prime} \mathrm{W}\right)$. Females with mature gonads were manually collected and transported to the laboratory, where they were kept in aquaria. These were placed in a water bath connected to an open system with circulating coastal seawater $\left(9.5-15{ }^{\circ} \mathrm{C}\right.$, corresponding to field temperatures during the period of collection; constant $31 \mathrm{psu}$ ), together with males, remaining unfed for maximally five days, until eggs were laid (females were checked daily). Every month (from March to December), samples of embryos in initial stage (meaning less than 1 day of embryonic development) were removed from five females and prepared for later analyses (see below). In females, carapace length (CL) was measured, and all embryos were counted. For thirty embryos from each female, embryonic length and width were measured under a stereo microscope, and embryo volume was calculated (Valdés et al. 1991). These embryos were subsequently divided into five replicate samples for further determinations of dry weight (DW) and elemental composition (carbon, hydrogen, nitrogen; collectively $\mathrm{CHN}$ ).

From August to February, females with embryos in a final stage of embryonic development were regularly collected from the same intertidal habitat. They were subsequently kept for maximally 5 days in individual aquaria without food $\left(10-15{ }^{\circ} \mathrm{C}\right.$; field temperatures during the period of collection; constant $31 \mathrm{psu}$ ), until Zoea I larvae hatched. The water was changed daily and checked for the 
presence of larvae. Thirty newly hatched larvae obtained from each of five females (carapace size measured as above) were divided in 5 replicate samples per female and stored frozen for later DW and CHN determinations.

From October to February, newly settled megalopae were collected monthly carefully with forceps from the intertidal zone (same habitat where the female with embryos were collected). In order to assure that megalopae collected for later determinations of DW and CHN had settled no more than $24 \mathrm{~h}$ before the day of collection, all megalopae were removed from the assigned collection areas (ca. 20 stones in average $700 \mathrm{~cm}^{2}$ each), one day prior to the collection. Twenty-five megalopae divided into five replicates were used for the analyses. Previous to CHN sampling, the megalopae were identified according to Albornoz and Wehrtmann (1996) and maintained one day in filtered seawater $(0.45 \mu \mathrm{m}$ pore size $)$ to allow them to empty the intestine.

All samples (embryos, Zoea I, megalopae) were washed with distilled water, frozen at $-80^{\circ} \mathrm{C}$, lyophilized for $48 \mathrm{~h}$, and stored at $-80^{\circ} \mathrm{C}$ for later determinations of DW and CHN. DW was measured on a Sartorius SC2 microbalance (precision $0.1 \mu \mathrm{g}$ ), CHN with standard techniques (Anger and Harms 1990) using an Elemental Vario Micro CHN analyser with Sulphanilamide as a standard.

\section{Statistical analysis}

To evaluate the effect of the factor season (month) on the measured variables in initial embryos, Zoea I, and megalopae, one-way ANOVA was applied. Tests for homogeneity of variance (Levene test) and normality (KolmogorovSmirnov test) were performed to check if the data set complied with the assumptions of parametrical tests; when the data did not meet these assumptions, differences among groups were assessed using a Kruskal-Wallis $H$ test. Multiple comparisons were carried out with Student-Newman Keuls test (SNK) (Zar 1999). Differences with a probability of error $P<0.05$ were considered as statistically significant.

\section{Results}

Embryo in an initial stage of development

The size of the females, from which embryos in an initial stage of development were sampled, fluctuated during the season of collection in a narrow range between 10.3 and $12.9 \mathrm{~mm} \mathrm{CL}(F=1.28, P=0.25)$. Embryo dry weight (DW) and volume showed significant variations within the reproductive season (March-December) (Fig. 1a, b; $F=6.06, P<0.001$ and $F=5.7, P<0.001$, respectively). Highest values of embryo DW were found near the beginning and the end of the reproductive season $(90 \pm 6$ and $95 \pm 4 \mu \mathrm{g}$, respectively; Fig. 1a), while a minimum was observed in August-September (transition winterspring, $76 \pm 5 \mu \mathrm{g}$ ). In general, significant differences were detected between the period August-September and the periods March-April (beginning) and October-December (end of the reproductive season; Fig. 1a). Seasonal variation in embryo volume showed a similar pattern as DW, ranging between $0.15 \pm 0.02 \mathrm{~mm}^{3}$ (December) and $0.12 \pm 0.02 \mathrm{~mm}^{3}$ (June), with smallest embryos observed in June and August (middle of the reproductive season; $P<0.05$, multiple comparisons; Fig. 1b). Within the size range of females sampled in this study (10.3-12.9 mm $\mathrm{CL}$ ), fecundity did not vary significantly during the season $\left(471 \pm 169\right.$ egg female $\left.{ }^{-1}, P>0.62\right)$. No relationship was observed between female size (within the size range sampled in this study) and embryo volume or DW.
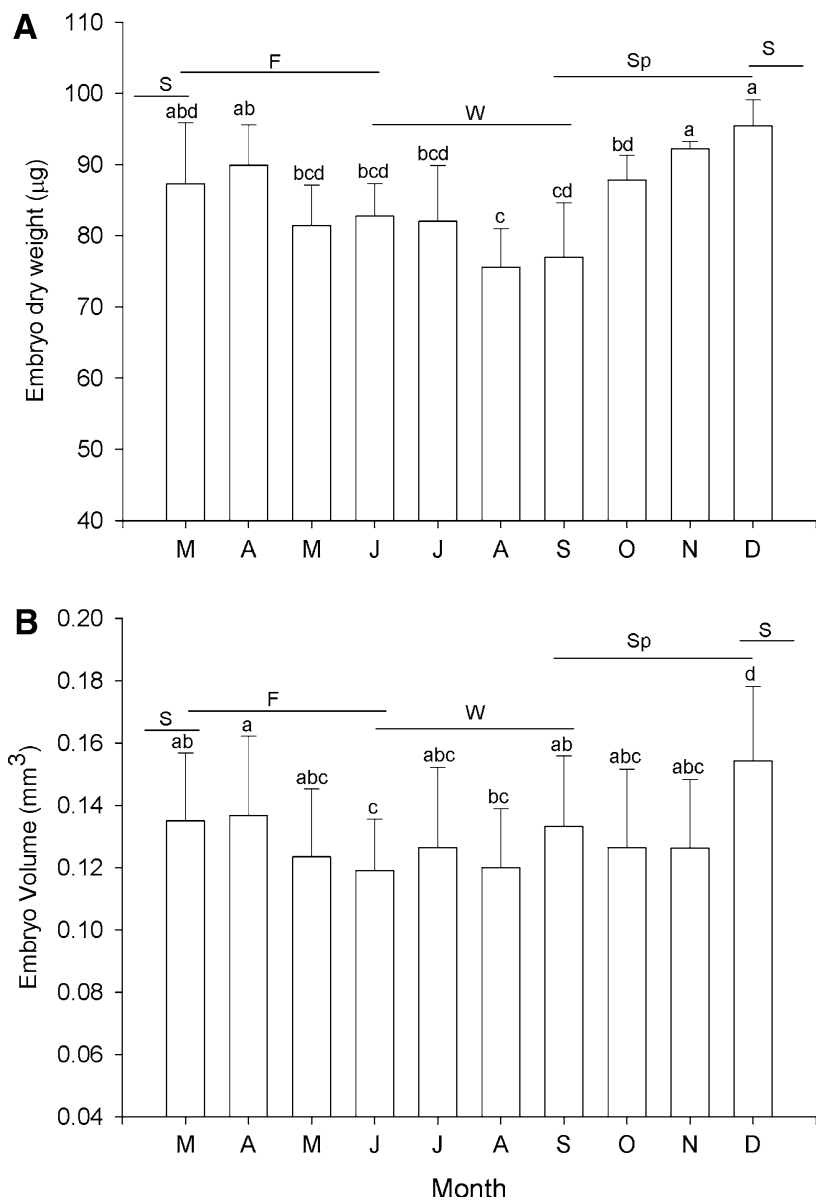

Fig. 1 Petrolisthes laevigatus, initial embryos during the reproductive season (2006) in the Seno de Reloncaví, Chile. a Dry weight $\left(\mathrm{DW}, \mu \mathrm{g}\right.$ ind $\left.^{-1}\right)$, b initial embryo volume $\left(\mathrm{mm}^{3}\right)$; mean + SD. Differences among months are indicated by different letters over the columns, $P<0.05$ based on multiple comparisons (Student-Newman Keuls test). $S$ summer, $F$ fall, $W$ winter, and $S p$ spring 
The initial embryos of $P$. laevigatus did not present significant seasonal variations in the percentage values of $\mathrm{C}$ and $\mathrm{H}$ (in $\%$ of DW; $P>0.05$; Fig. $2 \mathrm{a}, \mathrm{c}$ ), while significant differences occurred in the percentage values of $\mathrm{N}$ ( $F=5.40, P<0.0001$, Fig. $2 b$ ). The highest percentage $\mathrm{N}$ values were found near the end of fall and in winter (Fig. 2b), differing from March, November, and December $(P<0.05$, multiple comparisons Fig. 2b).

The absolute $\mathrm{CHN}$ values ( $\mu \mathrm{g}$ ind $^{-1}$ ) measured in initial embryos varied significantly during the reproductive season $(F=5.69, P<0.001 ; F=3.96, P<0.01 ; F=3.14$, $P<0.001$, in $\mathrm{C}, \mathrm{N}$, and $\mathrm{H}$, respectively). These measures of organic embryo biomass showed similar seasonal patterns as total DW, with generally highest values near the beginning (transition summer-fall) and the end (transition spring-summer) compared to the values measured in the middle of the reproductive season (August, September; Fig. 2d-f, multiple comparisons $P<0.05)$.
The C:N ratio, which is considered as an indirect estimate of the lipid:protein ratio and an indicator of the quality of initial embryos, showed significant seasonal variation $(F=9.3, \quad P>0.0001, \quad$ Fig. 3a $)$, fluctuating between $6.05 \pm 0.09$ (March) and 5.61 \pm 0.11 (June) $(P<0.05$, multiple comparisons). The lowest values occurred in the middle of the reproductive season (May, June, July), indicating a higher proportion of proteins in relation to the lipid fraction of embryo biomass in transition fall-winter as compared to the beginning (March and April) and the end of the season (November and December) (multiple comparisons, $P<0.05$, Fig. 3a).

The energy content of initial embryos (both per individual and per mg DW; estimated from the C content; Salonen et al. 1976) showed significant seasonal variations ( $H=21.1, P=0.01$ and $F=5.46, P<0.0001$; Fig. 3b, $\mathrm{c}$, respectively). The highest values were observed at the beginning and the end of the reproductive season
Fig. 2 Petrolisthes laevigatus, initial embryos during the reproductive season (2006) in the Seno de Reloncaví, Chile. Graphs a-c percentage contents of carbon $(C)$, nitrogen $(N)$, hydrogen $(H)$ (all in \% DW); d-f CHN contents per embryo (in $\mu \mathrm{g}$ ind $\left.^{-1}\right)$; mean $+\mathrm{SD}$. For further explanations, see Fig. 1
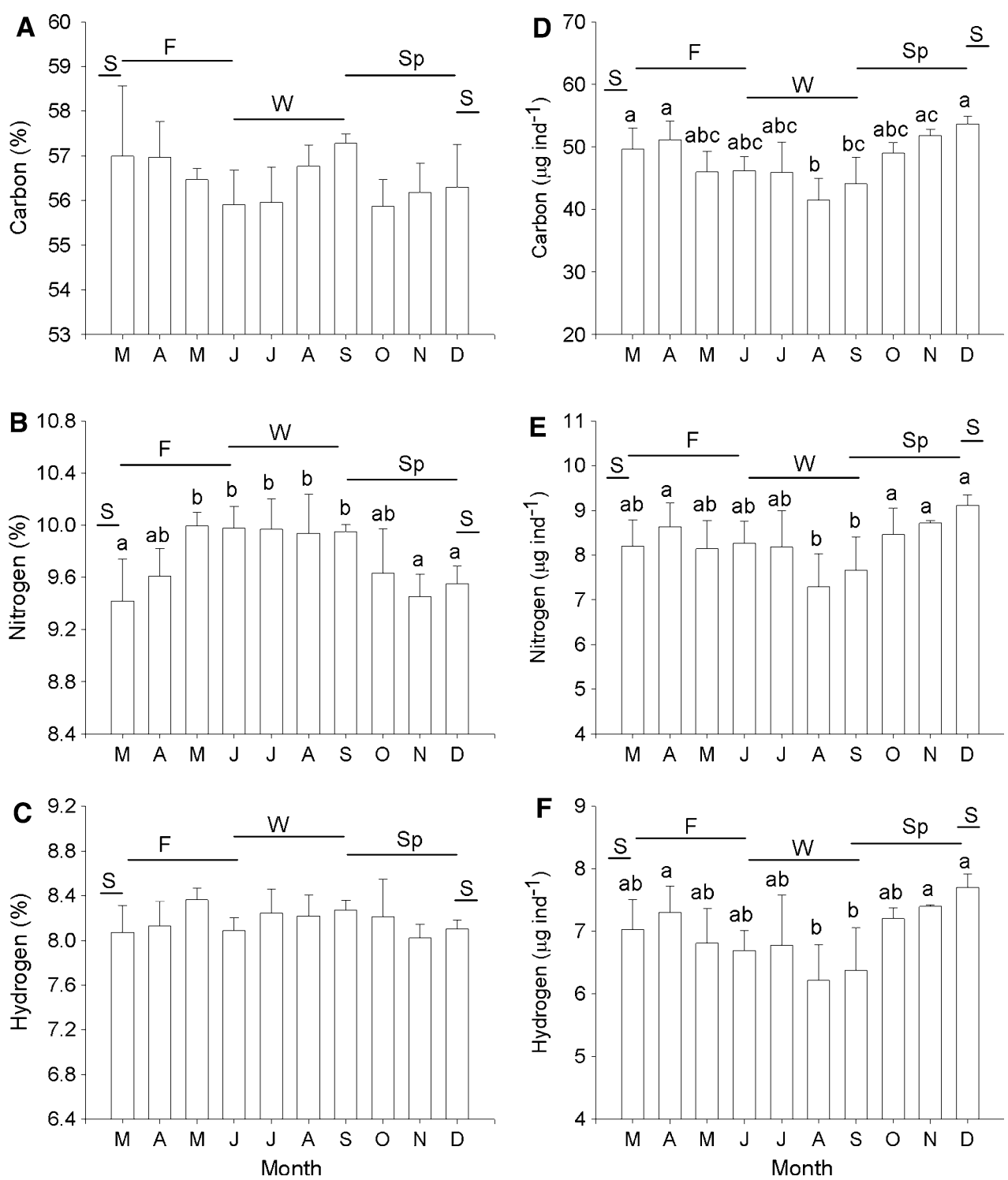

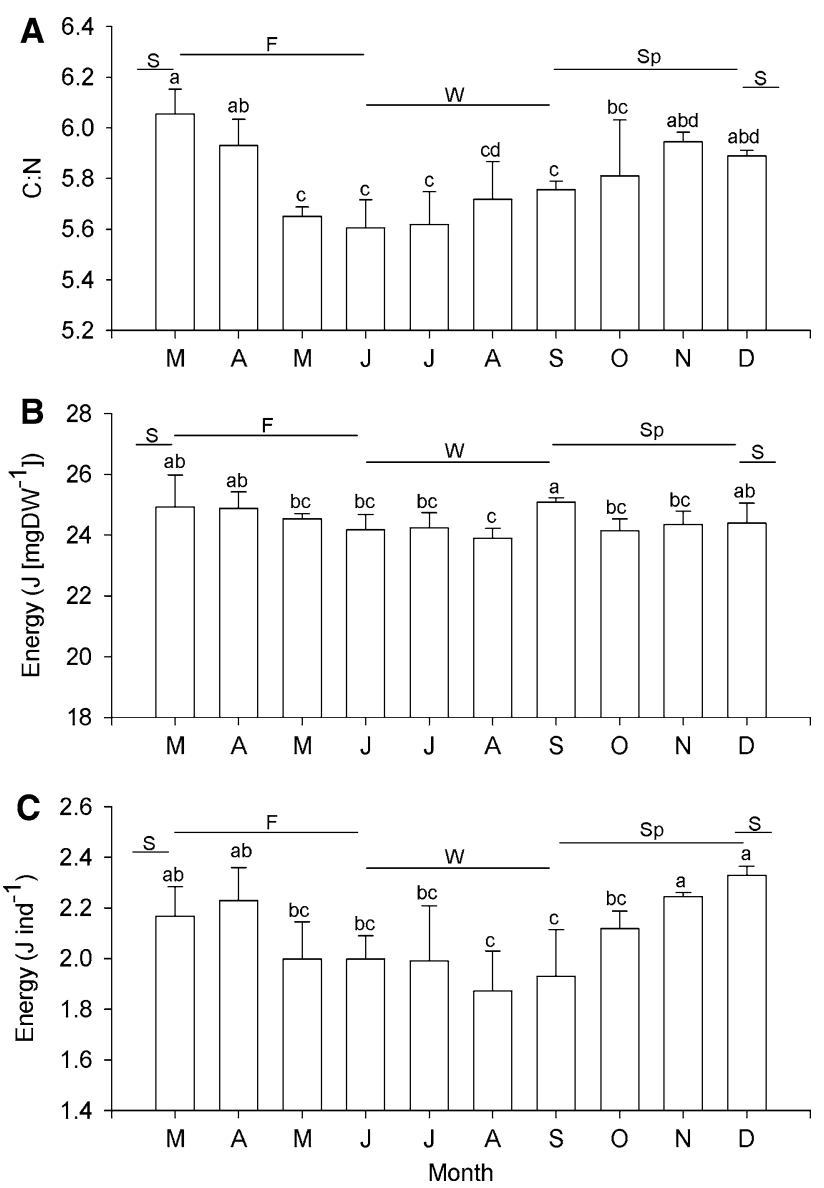

Fig. 3 Petrolisthes laevigatus, initial embryos during the reproductive season (2006) in the Seno de Reloncaví, Chile. a C:N mass ratio; b mass-specific energy content $\left(\mathrm{J}[\mathrm{mg} \mathrm{DW}]^{-1}\right)$; c energy content per embryo $\left(\mathrm{J}\right.$ ind $\left.^{-1}\right)$; mean $+\mathrm{SD}$. For further explanations, see Fig. 1

$\left(2.17 \pm 0.12\right.$ and $2.33 \pm 0.03 \mathrm{~J}$ ind $^{-1}$, respectively), while a minimum occurred in the middle of the season (August and September), i.e. in late winter $\left(1.87 \pm 0.16 \mathrm{~J}_{\text {ind }}{ }^{-1}\right)$ $(P<0.05$, multiple comparisons, Fig. 3c).

Newly hatched Zoea I larvae (ZI)

The hatching season of $P$. laevigatus lasted in the Seno de Reloncaví from August to February. The size of the females from which we obtained newly hatched zoeae (ZI) fluctuated between 11.5 and $12.7 \mathrm{~mm} \mathrm{CL}(F=1.33$, $P=0.27$ ). Larval dry weight (DW) at hatching showed significant seasonal variations $(F=3.47, \quad P<0.01$; Fig. 4a), with heaviest zoeae observed near the beginning and at the end of the season of larval release $(94.9 \pm 2.4$ and $88.9 \pm 2.5 \mu \mathrm{g}$ DW in late fall and summer, respectively) compared to those released in the middle of the hatching season (December) $(P<0.05$, multiple comparisons). Likewise, the CHN content per larva (in $\mu \mathrm{g}$ ind $^{-1}$ ) varied significantly among sampling months $(F=6.29$, $P<0.0001 ; F=4.32, P<0.01 ; F=8.20, P<0.0001$; for $\mathrm{C}, \mathrm{N}$, and $\mathrm{H}$, respectively; see Fig. 4b-d). The highest C and $\mathrm{H}$ values were found at the beginning and the end of the season $\left(\mathrm{C}: 33.7 \pm 2.4\right.$ and $31.2 \pm 1.3 \mu \mathrm{g}_{\text {ind }^{-1}}$; $H: 4.7 \pm 0.27$ and $4.5 \pm 0.18 \mu \mathrm{g}^{\text {ind }^{-1}}$ in August and February, respectively), showing significant differences to December $(P<0.05$, multiple comparisons). The $\mathrm{N}$ content of the ZI was maximum in August, at the beginning of the hatching season $\left(7.69 \pm 0.1 \mu \mathrm{g}\right.$ ind $\left.^{-1}\right)$, decreasing by approximately $13 \%$ in December (multiple comparisons, $P<0.05$; Fig. 4c).

The percentage $\mathrm{N}$ values (in \% of DW) also varied significantly during the season, fluctuating between $8.7 \pm 0.2 \%$ in September and $7.5 \pm 0.5 \%$ in February, respectively $(F=3.25, P<0.01$; multiple comparison, $P<0.05$ ). The percentage $\mathrm{C}$ and $\mathrm{H}$ values, by contrast, did not show significant seasonal variations, with average values of $35.9 \pm 0.7$ and $5.2 \pm 0.2 \%$, respectively.

The C:N mass ratio measured in newly hatched zoeae was maximum near the end of the season, in February (4.69 \pm 0.28$)$, differing significantly from values measured in September, October, November, and December $(P<0.05$, a posteriori comparisons). This indicates a higher proportion of lipids in relation to the protein fraction (Fig. 4e). The energy content per newly hatched ZI (in $\mathrm{J}$ ind ${ }^{-1}$, estimated from C data; Salonen et al. 1976) was ca $15 \%$ higher near the beginning (August) compared to the middle of the season (November and December; $F=5.16, P<0.001$; multiple comparisons, $P<0.05$; Fig. 4e). However, no significant seasonal variation was detected in the weight-specific energy content (average: $12.6 \pm 0.3 \mathrm{~J} \mathrm{mg} \mathrm{DW}^{-1}$ ).

Newly settled megalopa

The settlement season of $P$. laevigatus lasted in the Seno de Reloncaví from October to February. The dry weight (DW) of recently settled megalopae fluctuated seasonally between $741 \pm 26$ and $586 \pm 26 \mu \mathrm{g} \mathrm{ind}^{-1}$ in October and December, respectively $(F=40.3, P<0.0001$; a posteriori comparisons $P<0.05$; Fig. 5a). Similarly, the absolute (in $\mu \mathrm{g}$ ind $^{-1}$ ) as well as the percentage values of CHN (in $\%$ of DW) varied significantly during the settlement season. The highest values were generally found near the beginning and at the end of the settlement season showing, in general, significant differences to December (Fig. 5b-g). The C:N ratio decreased from October towards the transition spring-summer and increased in January $(F=9.16$, $P<0.0002$; Fig. 6a). Again, this indicates seasonal variations in the proportions of lipid and protein in newly settled larvae, differing between November-December and October-January $(P<0.05$, a posteriori comparisons, Fig. 6a). Also, the energy content (both expressed in $\mathrm{J}$ ind $^{-1}$ and in $\mathrm{J} \mathrm{mg} \mathrm{DW}^{-1}$ ) varied significantly throughout the settlement season $(F=59.3, P=0.0001 ; F=17.3$, 
Fig. 4 Petrolisthes laevigatus, newly hatched Zoea I during the hatching season (2006-2007) in the Seno de Reloncaví, Chile. a Dry weight; b carbon; c nitrogen; d hydrogen content (all in $\mu \mathrm{g} \mathrm{ind}^{-1}$ ); e C:N mass ratio; f. energy content per larva $\left(\mathrm{J}_{\text {ind }^{-1}}\right)$; mean $+\mathrm{SD}$. For further explanations, see Fig. 1
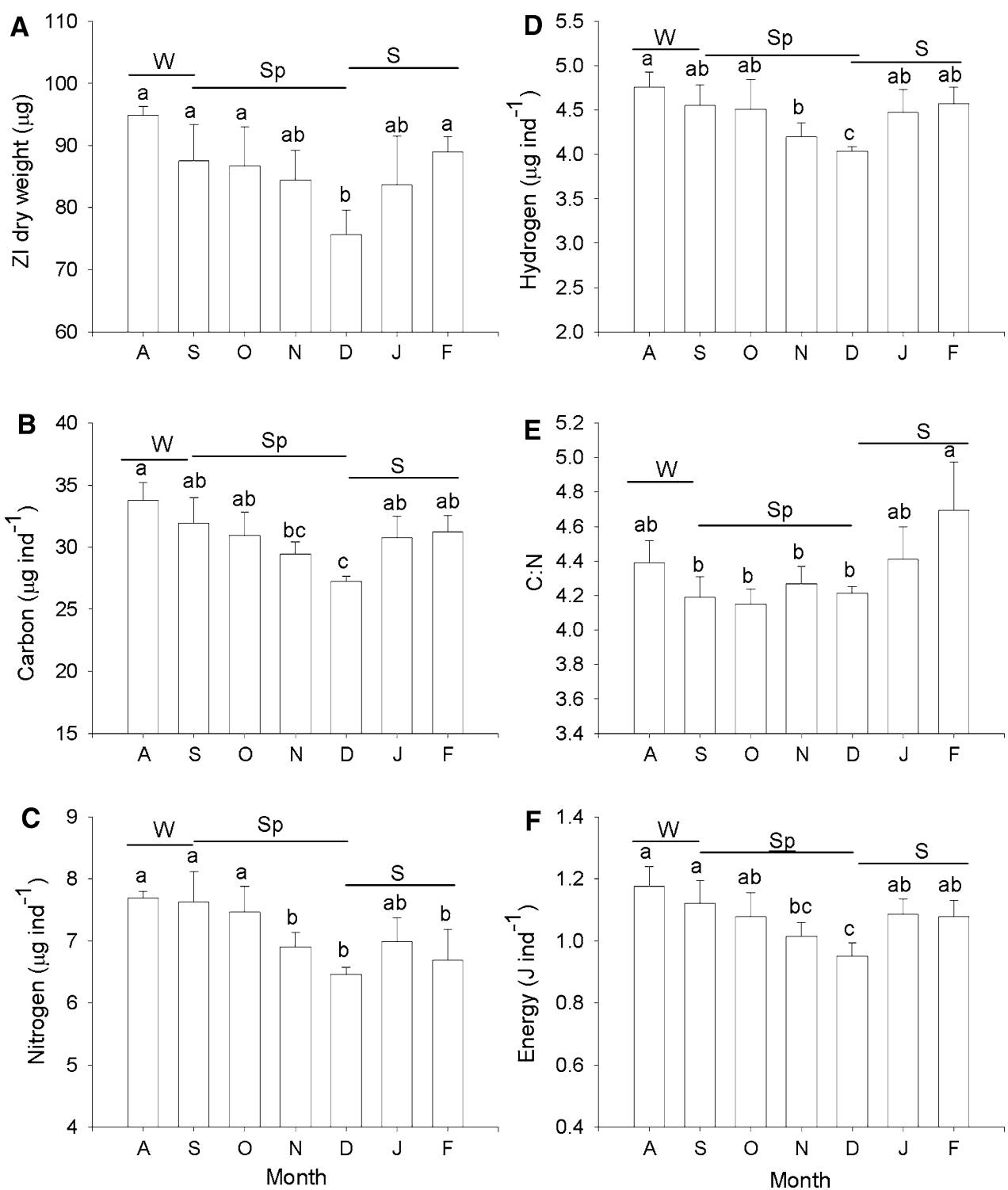

$P<0.0001$, respectively; Fig. 6b, c). This seasonal pattern was similar to that described above for early embryos and newly hatched larvae. Settling megalopae contained in October and February about 44 and $22 \%$, respectively, more energy (in $\mathrm{J}_{\text {ind }}{ }^{-1}$ ) than in December. The multiple comparisons revealed four groups according to their energetic content $\left(\mathrm{J} \mathrm{ind}^{-1}\right)$, those settled in (a) October, (b) November, (c) December, and (d) January-February $(P<0.05$, a posteriori comparisons).

\section{Discussion}

In the Seno de Reloncaví, near the southern limit of the geographic distribution range of $P$. laevigatus, various bioenergetic traits of early developmental stages (initial embryos, newly hatched Zoea I larvae, newly settled megalopae) showed significant seasonal variations. In general, the elemental constituents $\mathrm{C}, \mathrm{H}$, and $\mathrm{N}$ (which are predominantly bound in the organic fraction of biomass) as well as the energy content (estimated from CHN data) of embryos and larvae were maximum near the beginning and the end of the respective seasons. Recurrent patterns of variability in bioenergetic traits may be considered as a strategy of this species, which may optimize larval survival and growth in a physically variable temperate environment, and ultimately, enhance the survival of progeny (see Hadfield and Strathmann 1996).

Since the embryonic stages are completely non-feeding, seasonal variations in biomass, chemical composition, and energy content of initial embryos may be considered as adaptive, if they later translate to maximum larval fitness (expressed as maximum larval energy content, allowing for reduced dependence on planktonic food), and if those 
Fig. 5 Petrolisthes laevigatus, newly settled megalopae during the settlement season (2006-2007) in the Seno de Reloncaví. a Dry weight $\left(\mu \mathrm{g}\right.$ ind $\left.^{-1}\right)$; b-d percentage contents of carbon, nitrogen, hydrogen (all in \% DW); e-g CHN contents per megalopa (in $\mu \mathrm{g} \mathrm{ind}^{-1}$ ); mean $+\mathrm{SD}$. For further explanations, see Fig. 1
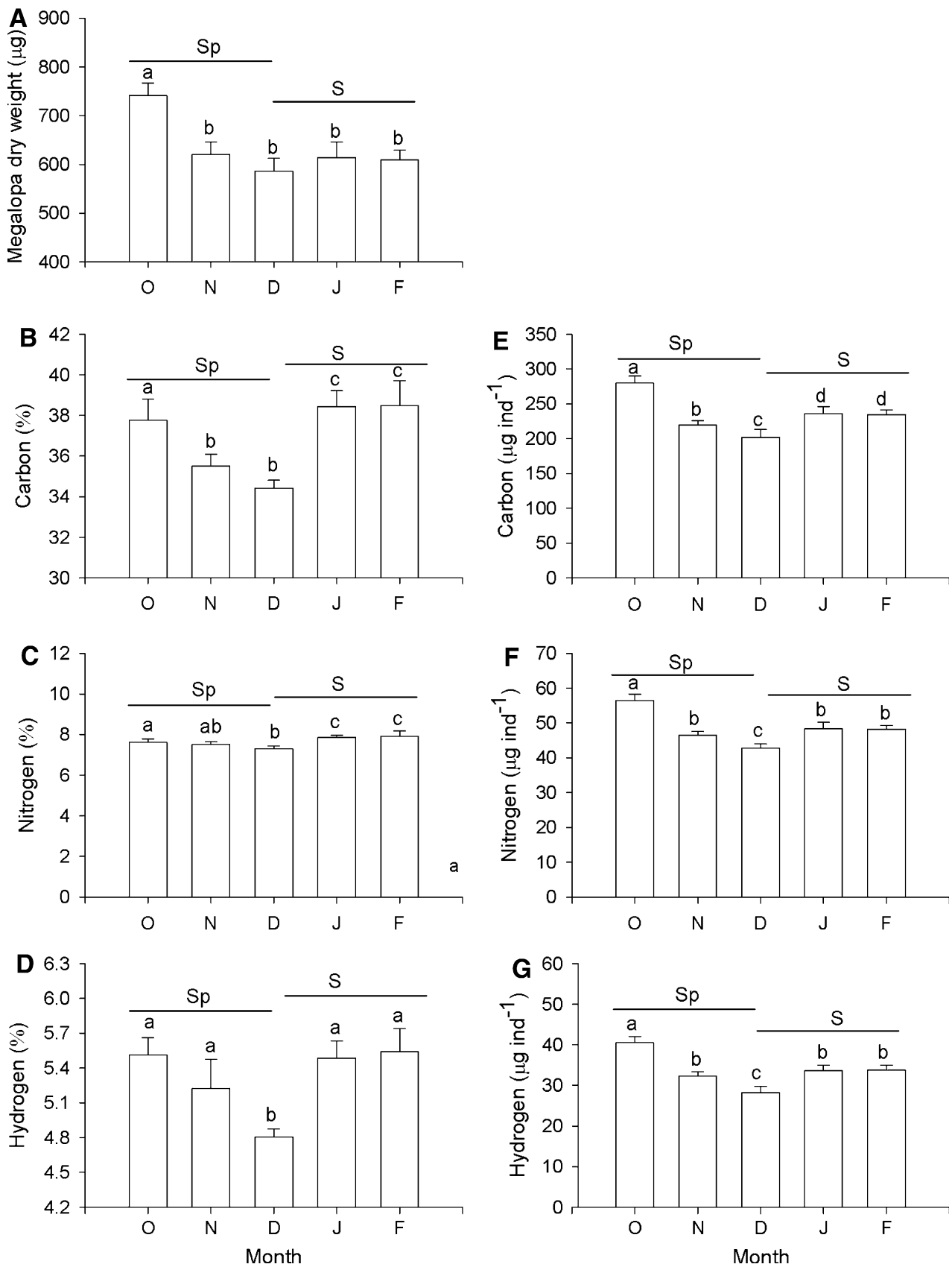

fitness maxima in the planktotrophic larval stages concur with a predictable pattern of exposure to adverse nutritional conditions. Our observations have shown that, due to temporal shifts in the seasons of egg laying, hatching, and settlement, the months of maximum biomass and energy content differ among these successive developmental stages. However, larger embryos (which also are heavier and richer in energy) tend to develop to heavier and fitter Zoea I larvae, and these may subsequently develop to heavier and fitter megalopae. These recurrent but seasonally shifting patterns in the initial biomass of embryos, newly hatched zoeae, and newly settled megalopae appear to indicate carry-over effects through successive life- history stages (see Anger 2006; Bas et al. 2008; Harrison et al. 2011).

While carry-over effects are plausible for the relationship between embryo biomass and larval energy content at hatching, the condition of settling megalopae does not exclusively depend on previously stored energy reserves, but also on larval feeding and metabolic energy losses in the plankton. Moreover, the megalopa has access to both planktonic and benthic food sources, so that it may depend less on plankton productivity than the pelagic zoeae. In conclusion, there may be confounding effects of seasonal changes in feeding rates and metabolic energy losses occurring during larval development. The importance of 

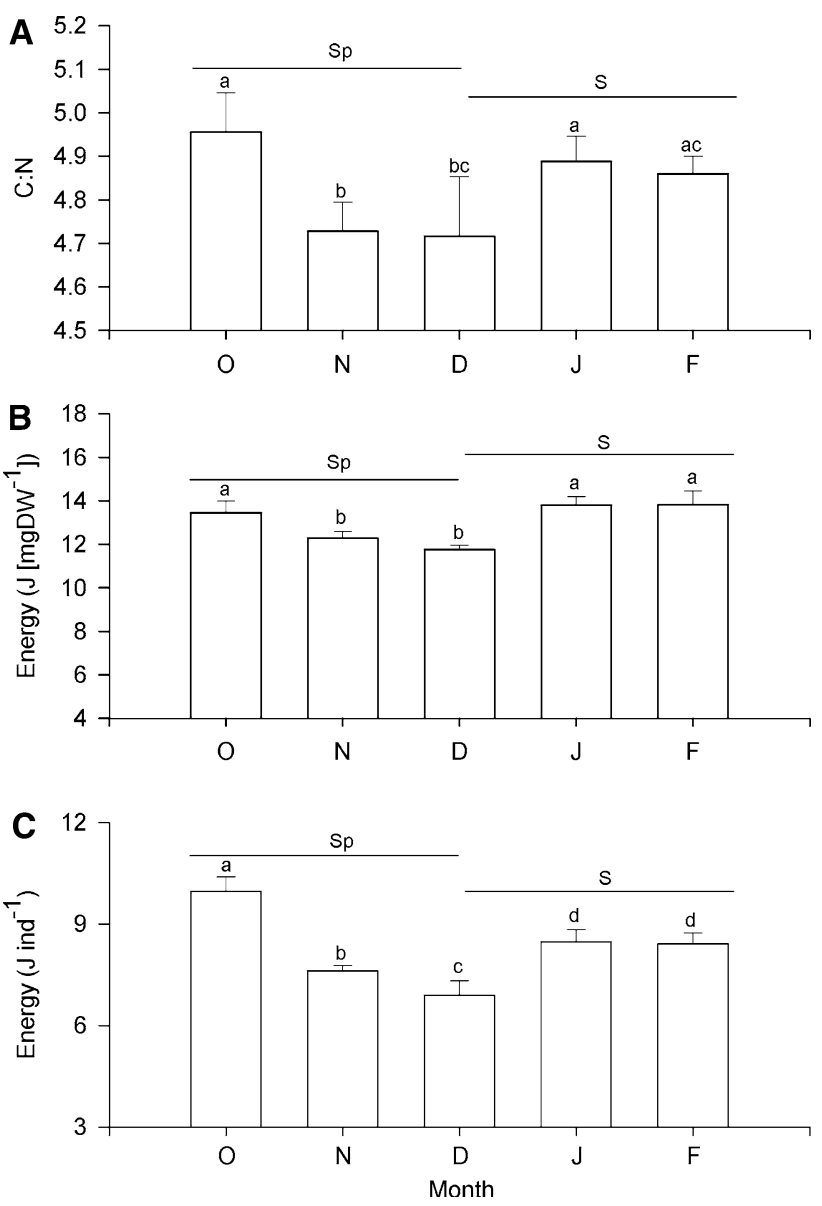

Fig. 6 Petrolisthes laevigatus, newly settled megalopae during the settlement season (2006-2007) in the Seno de Reloncaví, Chile. a $\mathrm{C}: \mathrm{N}$ mass ratio; b mass-specific energy content $\left(\mathrm{J}[\mathrm{mg} \mathrm{DW}]^{-1}\right)$; c energy content per megalopa $\left(\mathrm{J}\right.$ ind $\left.^{-1}\right)$; mean $+\mathrm{SD}$. For further explanations, see Fig. 1

seasonal variation in the biomass of the megalopa stage at settlement remains thus to be further scrutinized in future studies, where metabolic parameters such as respiration and the activities of metabolic enzymes should also be considered (Meyer et al. 2002; Rotllant et al. 2010).

In order to evaluate the importance of seasonal variations in embryonic biomass, it must be ascertained if the timing of maximum larval fitness at hatching or at settlement coincides with an occurrence of trophic limitations or other environmental challenge. As all fjords in the South of Chile, the Seno de Reloncaví presents marked seasonality in primary productivity, with blooms in spring and fall (Palma and Silva 2004; Iriarte et al. 2007; Iriarte and González 2008; González et al. 2010), and temperature (Gebauer et al. 2007; Iriarte et al. 2007). Variations in bioenergetic traits of initial embryos observed in our study could thus be a consequence of seasonal variations either in the availability and conversion of benthic or planktonic food and, alternatively or additionally, in endogenously controlled female energy investments in egg production. During winter, the availability of food for suspension feeders such as $P$. laevigatus is actually lower in the study area (Iriarte and González 2008; González et al. 2010), which may explain the production of eggs with a lower energy content in winter (Fig. 3). Better food availability in fall and spring (i.e. at the beginning and the end of the reproductive season) may thus allow the females to invest more energy per embryo, as observed in our study.

In addition to presumable effects of variable food availability in the benthos, there may also be endogenous factors influencing the energy allocation into egg production. Female $P$. laevigatus pass through at least two reproductive cycles during each season (Gebauer, personal observation), which also might contribute to a lower quality of embryos in the middle of the season due to reproductive exhaustion (see Palacios et al. 1999; Bas et al. 2007). However, poor embryonic quality should in this case be expected, but has not been observed, at the end of the season of egg production (December). This might be due to a compensating effect of greater availability of suspended food in spring and summer. Poor nutritional conditions in the benthos in winter may thus either cause directly a production of smaller eggs with less energy per embryo, or seasonal variation in food availability may serve as a triggers from the habitat, which could tune the endocrine control system involved in egg production (for recent review, see Nagaraju 2011). In the latter case, however, also other environmental variables, in particular, decreasing day length or low water temperatures may be perceived and used as environmental signals, alone or in combination with nutritional or further factors that are characteristic of winter conditions (Urzúa et al. 2012).

The variations in bioenergetic traits of newly hatched Zoea I larvae reflect those observed in the initial embryos and, possibly, variable utilization of metabolic substrates during embryonic development under different environmental conditions (see Giménez and Anger 2001). Our data suggest that variations in the bioenergetic traits of initial embryos are later carried over to first-stage larvae, leading to maximum biomass and energy values observed at the beginning of the hatching season (i.e. in winter). Although these newly hatched zoeae still are planktotrophic, displaying a high nutritional vulnerability (Gebauer et al. 2010), their enhanced energy content may allow them to develop also under unfavourable winter conditions with poor food availability in combination with low temperatures prevailing at the beginning of the hatching season. These adverse conditions prolong the duration of the Zoea I stage to about twice the time needed by larvae hatching with less energy in December (Gebauer et al. 2010).

Seasonal variations in reproductive traits have also been detected in the elemental composition and energy content 
of eggs and first-stage larvae of various other decapod crustaceans such as shrimp (Crangon crangon; Boddeke 1982; Paschke et al. 2004; Urzúa et al. 2012; Crangon spp.; Kattner et al. 1994) and crab (Neohelice granulata; Bas et al. 2007). Heavier embryos and larvae with higher energy and $\mathrm{C}: \mathrm{N}$ values were also in these species observed at the beginning of the seasons of egg laying and hatching, indicating an enhanced lipid content. These authors suggested that larvae presenting a greater biomass or energy content would be especially well adapted to survive and develop under unfavourable conditions, e.g. food limitation in combination with low temperatures, encountered especially at the beginning of the hatching season (Anger 2001; Giménez and Anger 2005; Gebauer et al. 2010).

In addition to the seasonal fluctuations in temperature and food supply mentioned above, also salinity varies in the study area, being particularly low in December (Gebauer 2004; Iriarte and González 2008), while the settlement rate of $P$. laevigatus is strongly reduced (Gebauer 2004; Gebauer et al. 2011). Hence, the relatively few megalopae that settle in the intertidal zone during this period may be exposed to conditions of lowsalinity stress.

Seasonal variations in the elemental composition and energy content of recently settled megalopae of $P$. laevigatus may have significant consequences for the performance of the subsequent juvenile stages, especially in seasonally fluctuating environments like that of the Seno de Reloncaví. To understand the population dynamics of $P$. laevigatus, the real contribution to recruitment (number and quality) must be known for megalopae settling in different periods of the season. Studies on the supply-side ecology of barnacles in Nahart (Massachusetts) and fish in Barbados and Florida Keys have shown great variability in traits of settlers, leading to variations in settlement success as well as post-settlement growth and survival (Jarret 2003; Sponaugle and Grorud-Colvert 2006).

Connections between life-history characteristics in successive developmental phases have been documented in numerous marine invertebrate species, probably exerting a significant impact on population dynamics (Giménez 2004, 2006, 2010; Beckerman et al. 2002; Giménez et al. 2004; Marshall and Keough 2006; Allen and Marshall 2010). As Pechenik (2006) pointed out, "metamorphosis is not a new beginning". In P. laevigatus, seasonal patterns of variation in larval fitness prior to metamorphosis resemble variations observed already at larval hatching, and even those in early embryos soon after egg laying. It is thus possible that patterns observed in biomass and elemental composition of early embryos are transferred not only to the newly hatched Zoea I, but eventually also through metamorphosis to the early juvenile stages, similar as observed in a crab, Neohelice granulata (Giménez et al. 2004; Bas et al. 2008).
Seasonal variability in bioenergetic traits of the early developmental stages of $P$. laevigatus observed in our study suggest that seasonal variation may be an important trait of this species, enabling it to inhabit environments with marked seasonal variations in food availability and temperature, so that it also can occupy a wide geographicclimatic range, in which it is subject to differential environmental selection pressures. Finally, this study clearly shows that seasonal variability in life-history traits must be taken into account in future research on this and other comparable species living in temporally or spatially highly variable environments.

Acknowledgments We thank Bettina Oppermann and Julia Haafke (Helgoland) for DW and CHN determinations. This study was supported by Fondecyt 1080157.

\section{References}

Albornoz LA, Wehrtmann IS (1996) Aspects of the reproductive biology of Petrolisthes laevigatus (Guérin, 1835) (Decapoda, Anomura Porcellanidae). Part II. Description of the larval development, including the first crab stage, cultivated under laboratory conditions. Arch Fish Mar Res 43:137157

Allen RM, Marshall DJ (2010) The larval legacy: cascading effects of recruit phenotype on post-recruitment interactions. Oikos 119:19771983

Anger K (2001) The biology of decapod crustacean larvae. Crustacean issue, vol 14. A. A. Balkema Publishers, Lisse

Anger K (2006) Contributions of larval biology to crustacean research: a review. Invert Reprod Dev 49:175-205

Anger K, Harms J (1990) Elemental composition (CHN), growth and exuvial loss in the larval stages of two semiterrestrial crabs, Sesarma curacaoense and Armases miersii. Comp Biochem Physiol 111A:615-623

Bas C, Spivak E, Anger K (2007) Seasonal and interpopulational variability in fecundity, egg size, and elemental composition $(\mathrm{CHN})$ of eggs and larvae in a grapsoid crab, Chasmagnathus granulatus. Helgol Mar Res 61:225-237

Bas C, Spivak E, Anger K (2008) Variation in early developmental stages in two populations of an intertidal crab, Neohelice (Chasmagnathus) granulata. Helgol Mar Res 62:393-401

Beckerman A, Benron T, Ranta E, Kaitala V, Lunberg P (2002) Population dynamics consequence of delayed life history effects. Trends Ecol Evol 17:263-269

Boddeke R (1982) The occurrence of winter and summer eggs in the brown shrimp (Crangon crangon) and the pattern of recruitment. Neth J Sea Res 16:151-162

Brante A, Cifuentes S, Pörtner H, Arntz W, Fernández M (2004) Latitudinal comparison of reproductive traits in five brachyuran species along the Chilean coast. Rev Chil Hist Nat 77:17-27

Connell J (1985) The consequence of the variation in initial settlement vs postsettlement mortality in rocky intertidal communities. J Exp Mar Biol 93:11-15

Gaines S, Rougharden J (1985) Fish and offshore kelp forests affect recruitment to intertidal barnacle populations. Science 235:479-481

Gebauer P (2004) Factores físicos y biológicos involucrados en el cierre del eslabón larval y reclutamiento de Petrolisthes laevigatus (Guerin, 1835) (Decapoda: Porcellanidae) en el Seno de Reloncaví. Doctoral thesis, Facultad de Ciencias, Universidad Austral de Chile, Valdivia, Chile 
Gebauer P, Paschke K, Moreno CA (2007) Reproductive biology and populational parameters of Petrolisthes laevigatus (Anomura: Porcellanidae) in southern Chile: consequences on recruitment. J Mar Biol Assoc UK 87:729-734

Gebauer P, Paschke K, Anger K (2010) Seasonal variation in the nutritional vulnerability of first-stage larval porcelain crab, Petrolisthes laevigatus (Anomura: Porcellanidae) in southern Chile. J Exp Mar Biol Ecol 386:103-112

Gebauer P, Freire M, Barria A, Paschke K (2011) Effect of conspecifics density on the settlement of Petrolisthes laevigatus (Decapoda: Porcellanidae). J Mar Biol Assoc UK 91:1453-1458

Ghiselin M (1987) Evolutionary aspects of marine invertebrate reproduction. In: Giese A, Pearse J, Pearse V (eds) Reproduction of marine invertebrates, vol IX. Blackwell Scientific Publications, Palo Alto, pp 609-665

Giménez L (2004) Marine community ecology: importance of traitmediated effects propagating through complex life cycles. Mar Ecol Prog Ser 283:303-310

Giménez L (2006) Phenotypic links in complex life cycles: conclusions from studies with decapod crustaceans. Integr Comp Biol 46:615-622

Giménez L (2010) Relationships between habitat conditions, larval traits, and juveniles performance in a marine invertebrate. Ecology 91:1401-1413

Giménez L, Anger K (2001) Relationships among salinity, egg size, embryonic development, and larval biomass in the estuarine crab, Chasmagnatus granulata Dana, 1851. J Exp Mar Biol Ecol 260:241-257

Giménez L, Anger K (2005) Effects of temporary food limitation on survival and development of brachyuran crab larvae. J Plankton Res 27:485-494

Giménez L, Anger K, Torres G (2004) Linking life history traits in successive phases of a complex life: effects of larval biomass on early juvenile development in an estuarine crab, Chasmagnathus granulata. Oikos 104:570-580

González HE, Calderón MJ, Castro L, Clement A, Cuevas LA, Daneri G, Iriarte JL, Lizárraga L, Martínez R, Menschel E, Silva N, Carrasco C, Valenzuela C, Vargas CA, Molinet C (2010) Primary production and plankton dynamics in the Reloncaví Fjord and the Interior Sea of Chiloé, Northern Patagonia, Chile. Mar Ecol Prog Ser 402:13-30

Grosberg R, Levitan D (1992) For adult only? Supply-side ecology and the history of the larval biology. Trends Ecol Evol 7:130-133

Hadfield MG, Strathmann MF (1996) Variability, flexibility and plasticity in life histories of marine invertebrates. Oceanol Acta 19:323-334

Harrison XA, Blount JD, Inger R, Norris DR, Bearhop S (2011) Carry-over effects as drivers of fitness differences in animals. J Anim Ecol 80:4-18

Hines A (1986a) Larval patterns in the life histories of brachyuran crabs (Crustacea, Decapoda, Brachyura). Bull Mar Sci 39:444466

Hines A (1986b) Larval problems and perspectives in life histories of marine invertebrate. Bull Mar Sci 39:506-525

Iriarte JL, González HE (2008) Phytoplankton bloom ecology of the inner sea of Chiloé, Southern Chile. Nova Herwigia 133:67-79

Iriarte JL, González HE, Liu KK, Rivas C, Valenzuela C (2007) Spatial and temporal variability of chlorophyll and primary productivity in surface waters of southern Chile $\left(41.5-43^{\circ} \mathrm{S}\right)$. Estuar Coast Shelf Sci 74:471-480

Jarret J (2003) Seasonal variation in larval condition and postsettlement performance of the barnacle Semibalanus balanoides. Ecology 84:384-390

Kattner G, Wehrtmann IS, Merck T (1994) Interannual variations of lipids and fatty acids during larval development of Crangon spp. in the German Bight, North Sea. Comp Biochem Physiol 107B(1):103-110

Lardies M, Wehrtmann I (1996) Aspects of the reproductive biology of Petrolisthes laevigatus (Guérin, 1835) (Decapoda, Anomura, Porcellanidae). Part I: reproductive output and chemical composition of eggs during embryonic development. Arch Fish Mar Res 43:121-135

Lardies AM, Arias MB, Bacigalupe LD (2010) Phenotypic covariance matrix in life-history traits along a latitudinal gradient: a study case in a geographically widespread crab the coast of Chile. Mar Ecol Prog Ser 412:179-187

Levin LA, Bridges TS (1995) Pattern and diversity in reproduction and development. In: McEdward LR (ed) Ecology of marine invertebrate larvae. CRC Press, Boca Raton, pp 1-48

Marshall D, Keough M (2006) Complex life cycles and offspring provisioning in marine invertebrates. Integr Comp Biol 46:643-651

Meyer B, Saborowski R, Atkinson A, Buchholz F, Bathmann U (2002) Seasonal differences in citrate synthase and digestive enzyme activity in larval and postlarval Antarctic krill, Euphausia superba. Mar Biol 141:855-862

Miner BG, McEdward LA, McEdward LR (2005) The relationship between egg size and the duration of the facultative feeding period in marine invertebrate larvae. J Exp Mar Biol Ecol 321:135-144

Moran AL, McAlister JS (2009) Egg size as a life history character of marine invertebrates: is it all it's cracked up to be? Biol Bull 216:226-242

Nagaraju GPC (2011) Reproductive regulators in decapod crustaceans: an overview. J Exp Biol 214:3-16

O'Leary Amsler M, George R (1984) Seasonal variation in the biochemical composition of the embryos of Callinectes sapidus Rathbun. J Crustacean Biol 4:546-553

Ouellet P, Plante F (2004) An investigation of sources of variability in American lobster (Homarus americanus) eggs and larvae: female size and reproductive status, and interannual and interpopulation comparisons. J Crustacean Biol 24:481-495

Palacios E, Perez-Rostro C, Ramirez J, Ibarra A, Racotta I (1999) Reproductive exhaustion in shrimp Penaeus vannamei reflected in larval biochemical composition, survival and growth. Aquaculture 171:309-321

Palma S, Silva N (2004) Distribution of siphonores, chaetognaths, euphausiids and oceanographic conditions in the fjords and channels of southern Chile. Deep-Sea Res 51:513-535

Paschke K (1998) Untersuchungen zum Energiestoffwechsel während der Embryonalentwicklung der Nordsee- Garnele Crangon crangon (Linnaeus 1758) (Decapoda: Caridea). Dissertation, Universität Hamburg, Germany

Paschke K, Gebauer P, Buchholz F, Anger K (2004) Seasonal variation in starvation resistance of early larval North Sea shrimp Crangon crangon (Decapoda: Crangonidae). Mar Ecol Prog Ser 279:183-191

Pechenik JA (2006) Larval experience and latent effects-metamorphosis is not a new beginning. Integr Comp Biol 46:323-333

Pfennig DW, Wund MA, Snell-Rood EC, Cruickshank TC, Schlichting D, Moczek AP (2010) Phenotypic plasticity's impacts on diversification and speciation. Trends Ecol Evol 25:459-467

Retamal M (1981) Catálogo ilustrado de los crustáceos decápodos de Chile. Gayana Zoología 44:1-256

Roff DA (1992) The evolution of life histories: theory and analysis. Chapman and Hall, New York

Rotllant G, Anger K, Durfort M, Sarda F (2004) Elemental and biochemical composition of Nephrops norvegicus (Linnaeus 1758) larvae from Mediterranean and Irish Seas. Helgol Mar Res 58:206-210

Rotllant G, Moyano FJ, Andres M, Estevez A, Diaz M, Gisbert E (2010) Effect of delayed first feeding on larval performance of the 
spider crab Maja brachydactyla assessed by digestive enzyme activities and biometric parameters. Mar Biol 157:2215-2227

Salonen K, Sarvala J, Hakala I, Viljamen ML (1976) The relation of energy and organic carbon in aquatic invertebrates. Limnol Oceanogr 21:724-730

Sampedro MP, Fernández L, Freire J, González-Gurriarán E (1997) Fecundity and reproductive output of Pisidia longicornis (Decapoda: Anomura) in the Ria de Arousa (Galicia, NW Spain). Crustaceana 70:95-110

Sponaugle S, Grorud-Colvert K (2006) Environmental variability, early life-history traits, and survival of new coral reef fish recruits. Integr Comp Biol 46:623-633

Stearns SC (1992) The evolution of life histories. Oxford University Press, New York
Urzúa A, Paschke K, Gebauer P, Anger K (2012) Seasonal and interannual variations in size, biomass and chemical composition of the eggs of North Sea shrimp Crangon crangon (Decapoda Caridea). Mar Biol 159:583-599

Valdés L, Alvarez-Osorio M, Gonzalez-Gurriarán E (1991) Incubation of eggs of Necora puber (1767) Decapoda, Brachyura, Portunidae). Volume and biomass changes in embryonic development. Crustaceana 60:163-177

Weiss M, Thatje S, Heilmayer O (2010) Temperature effects on zoeal morphometric traits and intraspecific variability in the hairy crab Cancer setosus across latitude. Helgol Mar Res 64:125-133

Zar JH (1999) Biostatistical analysis. Prentice Hall, Princeton 